\title{
OWN EXPERIENCES OF ABORTION IN DESCRIPTIONS OF PEOPLE ASSOCIATED IN PRO-CHOICE GROUPS ON FACEBOOK IN POLAND
}

\author{
KLEMENTYNA KULETA ${ }^{1}$ \\ ${ }^{1}$ The Maria Grzegorzewska University, Szczęśliwicka 40, 02-353 Warszawa, Poland. ORCID: 0000- \\ 0002-4391-2515, Email: klementynakuleta@gmail.com
}

\begin{abstract}
A restrictive anti-abortion law is in force in Poland. However, many people terminate pregnancy in cases other than those specified in the Act. Public discourse on this subject is dominated by philosophical and legal issues, and it lacks the voices of those who terminated the pregnancy. Abortion is often presented as a sad necessity, as always difficult or traumatic. I conducted research on describing own abortion experiences by people from Facebook pro-choice groups. 99 respondents who had 102 abortions completed an anonymous online questionnaire. From the material of answers, I selected categories that were used to analyze the results of the study: positive emotions, negative emotions, pregnancy as a burden, good experience, difficulty experience, stigmatization, support. It turned out that the experiences of termination of pregnancy were diverse. Respondents, describing their experiences, discussed topics rarely present in the discourse, such as the fact that abortion can be a good experience. KEYWORDS: abortion, termination of pregnancy, pro-choice, discourse about abortion, experience of abortion
\end{abstract}




\section{INTRODUCTION}

In Poland, the Catholic Church has a significant impact on public life, and the abortion law, introduced in 1993, is one of the most restrictive in Europe. In most cases, it prohibits abortion. Although it does not provide for a punishment for a person terminating a pregnancy, it entails criminal liability, for example for a doctor who performs an abortion contrary to the Act. Because the premises contained in the Act are formulated in general terms, doctors prefer not to risk and refuse to perform procedures. This is called the freezing effect (Grzywacz et al. 2013), which negatively affects the availability of even theoretically legal abortions (i.e. in the case of fetal malformations, risk to the health and life of a pregnant woman, rape or incest). The situation is additionally hindered by the lack of reliable sex education, insufficient reimbursement of modern contraception, the need to obtain a prescription for the purchase of emergency contraception or limited access to prenatal tests (Nowicka 2007).

In 2016, an attempt was made to enact an even more drastic ban on abortion - including imprisonment of a person aborting her own pregnancy and a ban on abortion in the event of pregnancy resulting from rape, fetal malformations and threat to the health of the pregnant person. The bill, however, caused mass protests in many cities throughout Poland and abroad. It was so-called A Polish Women's Strike took place on October 3, 2016. Two days later, the bill was rejected.

The current act is a fiction not only because it is difficult to get an abortion in cases permitted by law, but also because in cases not covered by the law, pregnancies are still being terminated. One of the ways to obtain this procedure is "abortion migration" so common that Slovak, German and Dutch clinics open Polish-speaking hotlines and websites (Grzywacz et al. 2013). For a fee you can also find a doctor who will informally terminate pregnancy in Poland. Medical abortion that can be carried out at home is becoming increasingly popular. It is available thanks to the organizations Women on Web and Women Help Women, which send sets of pills, among others to Poland.

The situation in which anti-abortion law turns out to be fiction is not surprising. According to Gail Kligman (2010), legal bans did not contribute to the termination of abortion in totalitarian countries (e.g. the USSR, Romania during Ceausescu's rule) or in countries considered Catholic (e.g. Poland, Brazil, not so long ago - Ireland). However, the ban makes abortion invisible to the public. Everyday life requirements cause people to behave in a different way than the one that political and religious systems try to impose on them. Women's health, especially the sphere of sexuality and birth control, are strongly associated with the dominant discourse of power, regarding issues such as family model, morality model, women's place in society (Żuk and Żuk 2017). According to Gail (Kligman 2010), worldwide reproduction policies of countries are associated with hypocritical rhetoric and actions. The formulation of reproduction legislation based on ideological and religious doctrines, without taking into account socioeconomic factors, leads to a deterioration in the quality of life for people, especially women and children.

A ban on abortion can also cause people to terminate a pregnancy in less secure conditions. 21.6 million dangerous abortions took place worldwide in 2008 , mainly in 
developing countries. Lack of access to legal and safe abortion affects women's lives 47,000 of them died in 2008 as a result of dangerous abortions (WHO 2011).

\section{DISCOURSE ON ABORTION IN POLAND}

The Catholic Church influences not only legislation, but also the language of the media and legal debate on abortion in Poland (Żuk and $\dot{Z} u k$ 2017). When adopting the ban on abortion, medical and social issues were ignored in the parliamentary debate, as were women's rights. The center of the debate was the embryo / fetus, called the "conceived child" (Wejbert-Wąsiewicz 2009). Instead of the voices of women and other people capable of becoming pregnant, the debate was dominated by the voices of men - priests, politicians, and doctors. The ban on abortion was introduced against the will of the majority of the population and despite collecting over a million signatures for a referendum on this matter (Nowicka 2007).

Researcher Ewelina Wejbert-Wąsiewicz indicates that in the Polish discourse on abortion, there is a strong polarization of attitudes in official culture and outside that moderate acceptance of abortion dominates (Wejbert-Wąsiewicz 2012). At the same time, various aspects of abortion are excluded from public discourse. Because ideological discourse has the greatest impact on other areas of discourse, abortion is not portrayed as a women's everyday life problem (Wejbert-Wąsiewicz 2012). Ideological discussions dominate the public debate, but real experiences rarely appear there. The abortion procedure in Poland is surrounded by huge taboos. It is possible that people who have experienced abortion often do not talk about it for fear of judgment and stigmatization. When a few weeks after the women's strike, singer Natalia Przybysz told the press about her experience of abortion, she met with a verbal aggression and insults, as well as protest letters demanding the cancellation of the concerts (Wejbert-Wąsiewicz 2017).

In the twenty years after the ban on abortion was adopted in Poland, the language of discourse was increasingly appropriated by opponents of the right to terminate pregnancy. Neutral terms have been replaced by emotionally defined terms - for example, instead of "abortion" the words "killing children", "murdering the unborn", instead of "embryo" or "fetus" the words "conceived child", "child", "unborn man" were used. A pregnant person is called a "mother". Terms such as "unborn holocaust" and "civilization of death" have also been used. (Wejbert-Wąsiewicz 2012). Anna Matuchniak-Krasuska (Szczuka 2004) noticed in the rhetoric of the opponents of the right to abortion the following polarizing measures: the elimination of neutral terms, the exclusion of "inappropriate" terms, the introduction of appropriate synonyms along with chosen epithets, and imposing meaning.

Strongly emotional language stuck to public debate more easily, while talking about “women's rights” was less present. Wejbert-Wąsiewicz (2012) sees the weaknesses of the feminist language in the fact that it is the "official" language, too far from the real experiences of women. Currently, although negatively marked terms are still used by opponents of reproductive rights, the language of feminists began to partially return to mainstream discourse - this was due to the strong social movements associated 
with the Women's Strike and Black Protest, as well as the creation of a movement to combat stigmatization abortion, in Poland associated with the group Abortion Dream Team. This movement aims to show abortion as a normal experience that is shared by a large part of society, and to show the diversity of abortion experiences. The group's goal is to prevent the association of abortion with evil and drama, with a decision that is always difficult and always ends in trauma. This way of talking about abortion - as a normal, universal experience, which is associated with various emotions, often with relief - can be distinguished from another way of talking about termination of pregnancy by supporters of the right to abortion - defensive. In the defensive discourse of abortion, abortion is said to be a sad necessity, termination of pregnancy is defined as a "lesser evil", it is said that "abortion should be legal, safe and rare", "abortion is the most difficult decision in a woman's life", "abortion it's always a drama." One of the opinions characteristic of this discourse is also "I am in favor of the right to abortion, but I would never do it myself". The allegations against this method of discourse are that it results from privileges - awareness of economic security and emotional situation, thanks to which one can enter the role of mother - and is a manifestation of the lack of solidarity towards the less well-off persons (Budgał 2011). The defensive way of talking about abortion is also accused of deepening the stigmatization surrounding this procedure.

On September 30, 2018, the March for the World Safe Abortion Day was organized for the first time in Poland. The march was co-organized by the Abortion Dream Team and is part of the discourse of the fight to stigmatize abortion and demand its full decriminalization. The next such march was held on September 28, 2019.

\section{LANGUAGES SURROUNDING ABORTION}

\section{“WOMEN-PROTECTIVE” LANGUAGE AND NORMATIVE FEMINITY}

The language used by proponents of the legality of abortion is similar in different countries. These anti-abortion movements often have religious connotations.

After legalizing abortion in the United States, opponents of abortion called for stricter rules, citing the fetus's right to life. Despite some influence on public opinion, this did not have clear effects on attitudes regarding the legality of abortion. Therefore, the tactics were changed and more women-centric claims were presented, but not supported by scientific evidence that abortion increases the risk of breast cancer, depression or suicide. This rhetoric results in the imposition of further restrictions on access to abortion, such as mandatory waiting periods (Jesudason and Weitz 2015). The argument about protecting women - from feeling regret after termination of pregnancy is also used to prohibit specific surgical abortion techniques (Jesudason and Weitz 2015). The protection of women's health has previously been used as the main argument for state law that abortion can only be performed in ambulatory surgical centers, although long-term studies have shown that abortion is a very safe procedure, and such restrictions reduce access to it (Jesudason and Weitz 2015).

In recent years, people who oppose abortion have been promoting the claim that abortion hurts women and does not help them (Ziegler 2013). While advocates of the 
right to abortion rely on arguments based on equality, opponents of abortion try to repaint their attitude as favorable to women or "protecting women". They often claim that abortion causes physical and psychological damage (Ziegler 2013).

Using the language of "protecting women" often causes them to be seen as passive. This may be the reason for the discrepancy between feminists and pro-choice doctors, because feminists approach abortion in a female-centric way and emphasize the self-determination of a pregnant person, while doctors can approach abortion in a medicalized way (Ziegler 2013).

Claims of the harmful effects of abortion on women's physical and emotional health also place abortion providers in the position of suspects who are not interested in women's well-being. Opponents of abortion often promote the traditional role of women in family and society. Also when formulating "protective-women" anti-abortion arguments, they treat them as passive, unable to make decisions (Ziegler 2013).

In the rhetoric of opponents of abortion, a woman decides to terminate pregnancy despite her real desires and against her own good, while restrictions on access to abortion are to help her make the right decision and protect a vulnerable woman from coercion by others (Millar 2017), and harmful effect of abortion (Millar 2017). This often justifies mandatory consultations for women in need of abortion. The assumption that the state must protect a woman from a decision she later regrets puts women as weak, vulnerable, potential victims, and at the same time means that a woman's judgment cannot be trusted (Millar 2017). This way of thinking assumes that women passively agree to abortion rather than actively want it, and also reflects the normative point of view that motherhood is the only unproblematic effect of pregnancy (Millar 2017). On the other hand, motherhood can be a reason for embarrassing and blaming certain groups of women - for example, teenage or using social help, perceived by politicians and the media as unable to emotionally and economically raise a child (Millar 2017).

Erica Millar analyzed the discourse about abortion, mainly in Australia. The researcher indicates that there is an emotional pattern in the social consciousness of how women experience abortion. It is described as an extremely difficult decision made in response to exceptional circumstances beyond the woman's control, which also includes a sense of regret and keeping an abortion secret due to guilt and shame (Millar 2017). Such a narrative belongs to a position which, according to the author, dominates the debate on termination of pregnancy, and which is both anti-abortion and pro-choice. In this rhetoric, regulating abortion is not so much a legal prohibition as combining abortion in the minds of people with a very difficult, destructive experience. Abortion, although it allows women to avoid unwanted parenthood, is rarely spoken of as a good experience - which can be associated with e.g. relief, happiness, gratitude or hope. Socially accepted talk of abortion includes feelings such as sadness, regret, guilt, shame and despair. It also means treating abortion as a unique and unusual event, unhappy or even harmful to women. This is despite the fact that abortion is a common experience, rarely causes side effects, and few women experience longterm negative feelings after it. According to Millar, normative femininity prevents us from perceiving abortion as a normal and rather unproblematic surgery. The source of representation of abortion in public awareness is not the experience of people who 
terminated pregnancy, but rather gender norms. Motherhood is perceived as the only one that brings women the promise of true happiness - especially pregnant women. As a consequence, a woman is seen as being able to choose to carry or terminate a pregnancy, but the latter option is considered an abnormal and harmful choice. This means that the decisions of women who want to terminate a pregnancy are still somehow controlled - if not because of legal restrictions and limited access to abortion, then because of the emotional meanings assigned to these choices (Millar 2017). The fetus or child is perceived as a "happy" object, so a woman who terminates a pregnancy is considered confused, unaware that the child will make her happy (Millar 2017). Motherhood in the social concept is combined with happiness and is no longer seen as a woman's destiny, but as her desire (Millar 2017).

However, it should be remembered that regret in social perception is irrevocably associated with the lack of children (and the end of reproductive time without becoming a mother), no regret is ever associated with their birth (Donath 2017). However, women's experiences do not necessarily reflect this belief. There are people who regret having become mothers - but this is a problem that comes with disbelief or stigmatizing women who confess such feelings. Often the existence of the phenomenon of regret of motherhood is simply denied (Donath 2017). There still remains a social belief that regretting not being a mother is inevitable and regretting motherhood impossible. This belief has a close connection with the normative perception of a woman as mother or potential mother. In this perception, only children can bring women true happiness, which leads the notion that abortion is always a harmful choice for her, and motherhood always a happy one.

Although in most cases regret is socially seen as undesirable, it can also be valued and recognized when adapted to prevailing standards (Donath 2017). It can even be used to maintain certain social values (Donath 2017). In the sphere of parenthood, expressing regret about abortion is socially more accepted and perhaps even expected than expressing regret about becoming a mother, which appears to many people as unimaginable. Regret can be a tool of oppression, a threat to people who want to terminate a pregnancy. The role played by women's experience of judgment and stigmatization is not taken into account, as well as the fact that they may feel relief, because abortion is one way to avoid entering into an unwanted motherhood relationship (Donath 2017).

Sometimes women in need of abortion are portrayed as victims of circumstances rather than conscious decision-makers (Millar 2017). In order to appeal for the sympathy of legislators and the public in general to make abortion legal, "desperate women" are often presented. They have abortions against their wish for baby due to miserable circumstance and they are regarded as objects that need to be saved by the good will of other people. In this approach, issues such as self-determination or body autonomy are not emphasized, and abortion is the result of the pregnant person's desire to ensure a good life for potential child - an act taken in baby's best interest (Millar 2017). Termination of pregnancy is perceived here as a difficult decision that women make out of a sense of love and duty towards a potential child, but contrary to their own nature (Millar 2017). In this approach, pregnant women irrevocably make a decision 
as a mothers, even when, paradoxically, they choose abortion (Millar 2017). A narrative about a difficult choice, often combined with emphasizing the reasons for abortion decisions, such as unfinished studies, lack of a good job or a permanent partner. Creating such justifications for termination of pregnancy concretizes the image of a "good mother" as an educated in a stable heterosexual relationship in a good financial situation. At the same time, this approach is expected from people in need of abortion to justify their decision to other people (Millar 2017).

\section{DECRIMINALIZATION}

Movements seeking to de-stigmatize abortion generally postulate not so much its legalization under certain conditions as full decriminalization. The situation in which abortion is not regulated by criminal law, removes formal obstacles to access to abortion and strengthens the discourse in which a pregnant person is treated subjectively - as a free individual who makes decisions (Millar 2017).

However, Millar (Millar 2017) points out that even in places where abortion has been decriminalized, the availability of surgery is still a key issue. Low economic status may limit access to abortion. On the other hand, because of the costs of parenthood, it can also push people to terminate even wanted pregnancies. Therefore, talking about "choice" becomes meaningless. When abortion is reduced to a matter of choice (Millar 2017), it simply appears as an individual decision. However, women do not become pregnant, do not become mothers and do not terminate pregnancy in a vacuum. The decisions about pregnancy and parenthood that they make, as well as the consequences of these decisions, cannot be separated from how factors such as gender, class or race position them, giving access to certain choices, closing to others and shaping a wider society - cultural meanings assigned to these decisions. To really talk about choice, you also need to treat abortion as a legitimate decision that a pregnant person can simply make.

\section{STIGMATIZATION}

Stigmatization of abortion can be understood as a social reaction to the rejection of norms regarding female sexuality and motherhood (Hanschmidt 2016). It can be described as manifesting in three ways. First, as the awareness of a woman about the negative attitudes of other people towards her abortion and the expectation that these attitudes can lead to discriminatory actions. Secondly, as internalizing negative attitudes, which can affect self-esteem, cause feelings of shame and guilt. Third, as actual experiences of discrimination and mistreatment related to termination of pregnancy. Stigmatization of abortion probably affects people who had this procedure, but it can also affect other groups - their partners or people who perform abortions.

It is worth remembering the mediating role that legislation can play in stigmatization. The law can strengthen the social construction of stigmatization by transforming moral disapproval into public policy through criminalization. In addition to criminal law, other legal norms that differentiate individuals can strengthen stereotypes. 
The law can also perform an expressive function by sending a message about behavior, identity and moral values, which strengthens the stigma (Abrams 2015).

Millar indicates that abortion is "awfulisated" (Millar 2017:15-16), that it is portrayed primarily in negative terms, from unpleasant to disgusting. Even if it is considered necessary, it is portrayed as something that should be avoided and which always causes a woman to despair. "Awfulisation" of abortion and its stigmatization mean that parenting is presented as the only problem-free pregnancy result. These phenomena are associated with emotions - for example, shame as an internalized abortion stigma.

Stigmatization of abortion, although it may be partly a product of legal prohibitions, may also help to create, justify and strengthen them. In countries where termination of pregnancy is legal, it may in turn make it more difficult to get it - by justifying the lack of adequate facilitation in accessing the procedure. Stigmatization may also discourage doctors from studying and taking up employment in the area of providing reproductive services. The cultural climate around abortion has measurable effects on its availability (Millar 2017).

Talking about your experience of abortion can be a way to counteract stigmatization, especially since the voices of people who terminated pregnancy are rarely heard in public discourse. In Poland, the discussion about abortion takes place on an ideological level, philosophical and legal aspects are raised - real experiences are rarely discussed. The embryo / fetus is at the center of the debate, the pregnant person is out of the way of interest. The absence of voices from people who have had an abortion may cause the discourse to be dominated by inadequate opinions about what the abortion person feels or "should" feel. Lack of talking about real experiences may cause that abortion appears to be more a theoretical discussion than life practice. It may seem a marginal phenomenon, while at least 4 million Polish women (between $1 / 4$ and $1 / 3$ of women living in Poland) had an abortion in their lives (CBOS 2013). Movements striving to destigmatize abortion - such as \#Shoutyourabortion or \#1na3 - focus on presenting real women's abortion stories. Each abortion “coming out” contributes to the normalization of abortion, perception of abortion as a universal phenomenon, associated with various emotions, not necessarily associated with trauma.

In the discourse on abortion, the terms "pregnant women", "women" or even "mothers" are often used. However, although cis-female make up the vast majority of abortions, the experience of abortion also applies to other people - like trans-men or non-binary people. The use of wording suggesting that only women terminate a pregnancy makes the experiences of other people invisible, which, although less numerous, are also present and important. Transgender or non-binary people can experience overlapping stigmatization, so it's even more worth creating a place for their experiences. On the other hand, talking about "women" emphasizes the fact that obstructing access to abortion is part of the broader history of discrimination against this gender or results from the social role attributed to it. Talking about "pregnant people" may slightly blur the historical and social significance of abortion. (Millar 2017) Perhaps there is a need to create new words and terms that would refer to the people who need or may need abortion, while not blurring the fact that it is about disadvantaged people. 


\section{METHOD}

I conducted the survey using my own questionnaire, which respondents completed anonymously online. Respondents answered questions, mostly open-ended, about their own experience of abortion. They related, among others to the reasons and degree of certainty of the decision on abortion, the emotions accompanying before, during and after the procedure, the importance of abortion for the life of the examined person, the degree of openness of talking about their own termination of pregnancy in conversations with other people and the support obtained. People were also asked to answer the question, if they could turn back time, would they decide to do abortion again. The subjects were free to choose how open they were - they did not have to answer every question to send a questionnaire. People who had more than one abortion completed the questionnaire several times - one for each experience.

From the empirical material obtained from the answers, categories were selected that were used to analyze the results of the study.

\section{SUBJECT, TIME AND PLACE OF RESEARCH}

The questionnaire was completed by 99 people who described 102 experiences of abortion (one person had two abortions, another one - three). They were people with pro-choice views. Respondents were sought after on Polish-language Facebook feminist and pro-abortion groups. Requests to complete the questionnaire were posted from November 2018 to March 2019, the surveyed people are mostly women (93), one trans man and one genderfluid person. Four people did not indicate gender. The age of the respondents was between 18 and 67 years old, one person did not specify the age. The age at the time of abortion was between 15 and 45 years. Among the respondents, 67 declared higher education, 29 secondary education, one person primary and one vocational education. One person did not indicate education. Among the respondents, three people described themselves as very religious, 6 as moderately religious, 13 as slightly religious, 76 as non-religious.

The subjects belong to a specific social category. Apart from belonging to prochoice groups, as it turns out, most respondents have a university degree and described themselves as non-religious. It is possible that results would be different if the survey were carried out outside a specific group. Being member in pro-choice groups can affects emotional way of experiencing abortion. However, it is important to listen to the voice of people who have had an abortion and to learn about their experiences. Focusing on a specific group that probably experiences a lower level of stigmatization can be a good start.

\section{RESULTS}

Subjects had surgical (56) and medical (44) abortions. One person injected the caustic agent. Ninety three abortions were carried out in the first trimester, five in the second 
(in a few cases there is no information).

Subjects gave various reasons for their abortion decision. The most frequent (41 times) was the reluctance to have a child - at all or at this moment in life. Other often mentioned are the economic situation (21 times), age and / or the desire to get an education (20 times). In 17 cases, factors related to the partner (aggressive partner, crisis in the relationship, but also no permanent partner) were given. In four cases, the reason for the abortion decision was medical factors related to the health and life of the pregnant person, in one - incurable fetal defect, in one - rape.

The degree of certainty of the decision to terminate pregnancy was assessed on a scale of 1 to 5 . The highest degree of certainty - 5 - was declared 85 times, 4 - 10 times, 3 - 4 times. One person described the degree of decision certainty as 2 and one as 1 .

Among the emotions that the subjects felt before the abortion, the most frequently mentioned (51 times) was fear/anxiety (before complications, potential failure of the procedure, that something would prevent abortion, that the family members find out). Some people (16) indicated that they were accompanied by strong expectation and impatience until they had the surgery behind them. For 10 people, the situation of unwanted pregnancy was a very difficult experience - due to physical ailments, deterioration of mental health, the inability to function normally. Two people described their suicidal thoughts that they had about being in an unwanted pregnancy. One of these people was a trans-man who felt strong fear and aversion to his body. The memory of pregnancy is unpleasant for him, although the attitude to terminating it is positive. Among the emotions after abortion, relief was most often mentioned (72 times). They also described positive emotions like joy (17 times), calm (12 times), gratitude (3 times), hope (3 times), and negative emotions like sadness (11 times), regret (6 times), guilt (4 times).

Over a dozen people reported psychological discomfort associated with the fact that their surgery was "unofficial", with the need to go abroad, with a sense of insufficient access to information or medical care.

In 89 cases it was declared that if it was possible to turn back time, the decision to terminate pregnancy would be the same, three people replied that they would have made a different decision (one most likely by mistake - this is indicated by her other answers), while seven people chose the answer "I don't know ". In the statements of two people who would like to turn back time and choose to carry the pregnancy to term, the same thing appeared - that pregnancy could be their only chance for motherhood. In the situation of one of these people, many factors contributed to the fact that abortion was a very difficult experience for her. This woman became pregnant in her early twenties, she met with negative reactions to pregnancy from her parents, she was urged to have an abortion, she did not receive support, she felt the need to hide the procedure, and later she could not get the wanted pregnancy (according to the doctor, infertility is not the result of abortion). For the second regretting woman, abortion was a difficult and unpleasant experience, accompanied by uncertainty. This person had previously suffered from depression.

In the stories of these two people there are factors that, according to the American Psychological Association, increase the likelihood of stronger negative emotional 
responses after abortion - such as previous mental health problems, the need for discretion, and being persuaded to abortion. Similar factors appear in the statements of people who declared that they do not know if they could turn back time, they would make the same decision. In addition to those already mentioned, they are: high religiousness, negative reaction to the pregnancy of people around, lack of support. For some people, abortion was a difficult experience, although they don't regret it. One of the respondents described that for some time after the surgery she felt emotional havoc. Another said that she did not like to think about her decision and it hurts her that she had to make it. Three other people described abortion as a difficult decision, and another two as a hard mental experience/experience that caused sadness. None of these people would like to undo their decision. Difficult emotions were associated with among others cases of termination of wanted pregnancies for medical reason.

For some respondents, termination of pregnancy was a good experience. Nine people reported that abortion was for them an experience strengthening the sense of control over their body and life. Twenty-six people, describing the importance of abortion for their lives, indicated that thanks to termination of pregnancy they realized their plans and regained the possibilities of completing education, developing a professional career, leaving a violent partner. Another nine people wrote that abortion was important for their lives because it allowed them to avoid unwanted parenthood. Five people described abortion as "release, liberation," another five said abortion "saved their lives." Several people have described abortion as a positive, empowering experience. One person indicated that in an unwanted pregnancy, she felt "delighted that abortion exists." Twenty statements made such expressions as "it was a good decision", "the best decision I could make", "one of my better decisions".

One of the more frequently appearing signs of stigmatizing abortion is that those who terminate pregnancy conceal their experience, fearing judgment from other people. Five of the respondents did not tell anyone about their abortion, the next six told some people around them only after the surgery. Fifty people indicated that they felt that they could not talk about their abortion with a person or people (it is often about some family members or friends). The reasons for this were generally a high degree of religiosity of potential interlocutors or anticipated negative reactions, rejection, lack of understanding, and stigmatization.

Perhaps the strategy of selectively telling about your experiences is somewhat effective, because 56 respondents have not encountered negative reactions to talking about their abortion. Eighteen people have encountered such reactions, most often from family or friends, but also medical staff (in the case of abortion for medical reasons).

In 55 cases, the respondents rated the support received from other people in an abortion situation as good or very good. Fifteen people rated it badly. In a few cases, this was ambiguous - support was only satisfactory from some people. Nine people indicated that other people could not support them because they did not know about abortion. Eight people declared that they did not need support.

Support methods that were most often indicated were conversations (mentioned 62 times), help in organizing pills/procedure (35 times), financial support (32 times) and 
providing information (15 times). The presence, help at home, care, hugging, lack of judgment and amenities at work (temporary change of working mode from standing to sitting) were also mentioned.

As people who provide support in the event of termination of pregnancy, the most frequently mentioned one was partner (in 48 cases), close friend (45 cases), other friends (17 times), parents (18 times), siblings (10 times). Eight people indicated that they received support from other family members, and four from doctors. A psychologist, psychotherapist and employer were also mentioned. Twenty-one respondents said that they did not receive support from anyone, some of them declared that they did not need or seek such support.

Thirty-four respondents asked if they thought people around them could change their mind about abortion or its legality, if they knew they had terminated the pregnancy, they answered yes. Talking about your experience, in the opinion of these people, makes or could make the support for the legality of abortion greater. Other people will see that their friends or family members terminate pregnacy and the lack of access to legal abortion is a problem more commonly than they thought. This could dispel various myths about abortion. Twenty people said that knowledge of their experience would not affect the views of other people, with two people indicating that their family and friends already have liberal views on abortion. Fifteen people answered "I don't know."

Some respondents said that they were talking about their abortion in order to fight stigmatization, inform others about possible options, and support other people in this experience.

\section{DISCUSSION}

The most frequently indicated reasons for termination of pregnancy suggest that these were abortions due to unwillingness to have a child or for socio-economic reasons. Only in 6 cases abortions were carried out for the reasons mentioned in the anti-abortion act, most of them were "illegal" abortions, in any case in accordance with applicable regulations in force in Poland. (Among the abortion experiences examined, 14-17 of them took place before the introduction of the anti-abortion law, and some of those who completed the questionnaire terminated their pregnancy abroad in countries where more liberal regulations apply). Therefore, in the surveyed group, the vast majority of respondents performed abortions for reasons in which Polish law did not provide for legal surgery (even if abortion did not take place in Poland during the ban). This suggests that the anti-abortion law is not being observed.

Abortion in public discourse in Poland is often presented in a stigmatizing way - in terms of evil and trauma, it is less often treated as an expression of self-determination, deciding about your body and life by a pregnant person. The social discourse rarely talks about the positive effects that termination of unwanted pregnancy can have. Some respondents present a different way of talking about abortion - as a good and strengthening experience. For some of the respondents, termination of pregnancy was a liberating experience, a source of a sense of strength and control over their 
lives. Many people indicated that termination of pregnancy allowed them to realize their life plans and regain their possibilities. In public discourse, where abortion is generally referred to as a difficult or traumatic experience, this way of thinking is hard to imagine. At the same time, for some of the respondents, abortion was indeed a difficult experience, in few cases regretted.

Although people who terminate pregnancies are often portrayed as victims of circumstances who agree to abortion rather than self-determined people who actively seek it, it turns out that most respondents were very convinced about their decision. Some of the respondents also reported that unwanted pregnancy was a difficult experience for them and/or that they were impatiently waiting for the procedure.

One of the most effective ways to fight abortion stigma it to create space for people who have had this procedure to tell their stories. The feeling of the need to maintain discretion, resulting from the fear of being judged or in some cases criminal penalties (threatening people helping in illegal abortions), causes that some people do not realize that they know people who terminated pregnancy. This can make them think that the problem of unwanted pregnancies and how to terminate them is marginal, while in fact at least one in four women in Poland has had an abortion.

The research has limitations. First of all, the subjects belong to a specific group. Apart from belonging to pro-choice groups, as it turns out, most respondents have a university degree and described themselves as non-religious. It would be very desirable to repeat similar studies on the general population of people with experience of abortion in Poland or to compare them with the results from another specific group people advocating a ban on abortion. It would be also desirable to reach more people. The research may be the starting point for subsequent surveys.

It is an interesting question whether the test results would be similar if they were carried out outside a specific group. It is possible that in this group, people who terminated pregnancy experience a lower degree of stigma than non-members in prochoice groups, and this affects their emotional way of experiencing abortion. More than a half of women in the survey regard their decision of abortion positive while they know it is sometimes stigmatized in their society. These people participate in many other social environments and may experience stigmatization there - as happened in the case of some respondents. Most of the respondents did not share their experience with some people, generally for fear of judgment and stigmatization. There is need for more extended survey but in this survey we can conclude that decriminalization on the legislative sphere and destigmatization on the ideological sphere are expected to remove the negative recognition and emotion around abortion from Polish society.

FUNDING: This research received no external funding.

CONFLICT OF INTEREST: The author declares no conflict of interest. 


\section{REFERENCES}

Abrams, Paula. 2015. “The Bad Mother: Stigma, Abortion and Surrogacy.” Journal of Law, Medicine \& Ethics 43(2): 179-191. https://doi.org/10.1111/jlme.12231

Budgał, Karina. 2011. „Jestem za prawem do aborcji, ale sama nigdy bym jej nie zrobiła. O sabotażu językowym.” Pp. 9-10 in A jak hipokryzja. Antologia tekstów o aborcji, władzy, pieniądzach i sprawiedliwości, edited by C. Snochowska-Gonzalez. Warszawa: Wydawnictwo O matko!

CBOS. 2013. Komunikat z badań. Doświadczenia aborcyjne Polek. Warszawa: Fundacja Centrum Badania Opinii Publicznej. BS/60/2013. Retrieved November 15, 2019 (https://www.cbos.pl/SPISKOM.POL/2013/K_06013.PDF).

Donath, Orna. 2017. Żałując macierzyństwa. Białystok: Wydawnictwo Kobiece.

Grzywacz, Anka et al. 2013. 20 lat tzw. ustawy antyaborcyjnej w Polsce. Warszawa: Federacja na Rzecz Kobiet i Planowania Rodziny. Retrieved November 15, 2019 (http:// federa.org.pl/wp-content/uploads/2017/07/raport_federacja_2013.pdf).

Hanschmidt, Franz. 2016. “Abortion Stigma: A Systematic Review.” Perspectives on Sexual and Reproductive Health 48(4): 169-177. doi: 10.1363/48e8516

Jesudason, Sujatha and Tracy Weitz. 2015. "Eggs and Abortion: 'Women-Protective' Language Used by Opponents in Legislative Debates over Reproductive Health.” Journal of Law, Medicine \& Ethics 43(2): 259-269. https://doi.org/10.1111/ jlme.12241

Kligman, Gail. 2010. Polityka obłudy. Kontrola rozrodczości w Rumunii pod rządami Ceausescu. Kraków: Universitas.

Millar, Erica. 2017. Happy abortions. Our bodies in the era of choice. London: ZED.

Nowicka, Wanda. 2007. „Prawa reprodukcyjne w Polsce.” Pp. 663-679 in Czarna księga kobiet, edited by Ch. Ockrent. Warszawa: Wydawnictwo W.A.B.

Szczuka, Kazimiera.2004. Milczenie owieczek. Rzecz o aborcji. Warszawa: Wydawnictwo W.A.B.

Wejbert-Wąsiewicz, Ewelina. 2009. „Wokół aborcji. O konflikcie wartości i emocji.” Pp. 201-224 in Emocje a kultura i życie społeczne, edited by P. Binder, H. Palska, W. Pawlik. Warszawa: Wydawnictwo IFiS PAN.

Wejbert-Wąsiewicz, Ewelina. 2012. Aborcja w dyskursie publicznym. Monografia zjawiska. Łódź: Wydawnictwo Uniwersytetu Łódzkiego.

Wejbert-Wąsiewicz, Ewelina. 2017. Bez retuszu czy po liftingu? Obrazy starości i aborcji w filmie. Łódź: Wydawnictwo Uniwersytetu Łódzkiego.

WHO. 2011. Unsafe abortion. Global and regional estimates of the incidence of unsafe abortion and associated mortality in 2008. Genewa: World Health Organization.

Ziegler, Mary. 2013. “Women's Rights on the Right: The history and Stakes of Modern Pro-Life Feminism.” Berkeley Journal of Gender, Law \& Justice 28: 232-268.

Żuk, Piotr and Paweł Żuk. 2017. "Women’s health as an ideological and political issue: Restricting the right to abortion, access to in vitro fertilization procedures, and prenatal testing in Poland.” Health Care for Women International 38(7): 689-704. https://doi.org/10.1080/07399332.2017.1322595 


\section{BIOGRAPHICAL NOTE}

Klementyna Kuleta holds an MA in Education. She obtained the title at the Maria Grzegorzewska University, Poland.

OPEN ACCESS: This article is distributed under the terms of the Creative Commons Attribution Non-commercial License (CC BY-NC 4.0) which permits any non-commercial use, and reproduction in any medium, provided the original author(s) and source are credited.

ARTICLE HISTORY: Received 2019-10-31 / Accepted 2020-02-15 
